\title{
Marine epibiosis. IV. The periwinkle Littorina littorea lacks typical antifouling defences - why are some populations so little fouled?
}

\author{
M. Wahl *, H. Sönnichsen \\ Zoologisches Institut, Universität Kiel, Olshausenstr. 40-60, W-2300 Kiel, Germany
}

\begin{abstract}
Epibiosis on the shells of Littorina littorea (L.) varies between populations. While snails from the Helgoland intertidal zone (North Sea) rarely carry any epibionts, subtidal snails from the Kiel Bight (Baltic Sea) are frequently fouled. This study shows that $L$. littorea lacks typical anti-fouling defence adaptations such as mechanical, physical or chemical defences. Our enclosure experiments suggest that epibiosis on the shells is inversely correlated to L. littorea population density. At high densities snails frequently pass over one another and subsequent grazing, bulldozing and/or foot mucus secretion may contribute to the inhibition of epibionts. Consequently, the observed differences in shell epibiosis between the $2 L$. littorea populations may to a large extent be explained by considerably higher $L$. littorea abundances in the Helgoland intertidal zone. Differences in habitat conditions probably play a secondary role. We suggest that the fouling inhibiting factors associated with high population density (mucus secretion, bulldozing, mutual grazing) are to be considered as a biological disturbance which effectively blocks recruitment by most potential colonizers.
\end{abstract}

\section{INTRODUCTION}

The colonization of abiotic and organismic surfaces by sessile micro- and macroorganisms is a common phenomenon in the marine environment. Any surface exposed in the sea must be (1) ephemeral, (2) regularly disturbed or (3) defended to escape fouling. Epibiosis, e.g. the association between bacterial, animal or plant epibionts and their substrate organism (basibiont), entails numerous benefits and disadvantages for both colonizing and colonized organism (Wahl 1989). The relative importance of the various effects of epibiosis depends on the biology and life history of epibionts and basibionts and on the characteristics of the environment. Thus, absence or presence of an anti-fouling defence in a non-ephemeral organism with an undisturbed body surface will be largely governed by whether the species' fitness is impaired by the effects of uncontrolled epibiosis and, if it is, whether it is weakened more by these disadvantages or by the (still

\footnotetext{
- Present adress: MRD, Scripps Institution of Oceanography,
} La Jolla, California 92122-0236, USA hypothetical) costs of anti-fouling defence. Naturally, total defence and unrestricted epibiosis tolerance are only the 2 extremes of a continuum.

The periwinkle Littorina littorea (L.) is a common gastropod grazer of northern Atlantic inter-and subtidal zones. The snail displays a wide ecological tolerance, thriving on different substrates (mud, sand, rock), in different salinities (35 to $13 \%$; Taylor \& Andrews 1988) and on a large variety of diets (diatoms, germlings, larvae, many ephemeral macroalgae; Lubchenco 1983, Petraitis 1983, Watson \& Norton 1985). The following observations made us take a closer look at this gastropod: North Sea L. littorea from the Helgoland intertidal zone rarely carry any (macro-) epibionts on their shell. Individuals of the same species from Kiel Bight (brackish Baltic Sea sublitoral, 2 to $6 \mathrm{~m}$ depth) exhibit a conspicuously higher degree of epibiosis. Both populations are less fouled than similarly exposed abiotic substrata in their environment.

In view of this and considering the longevity of Littorina littorea (more than $5 \mathrm{yr}$; K. Janke pers. comm.), their reduced degree of epibiosis, especially in the Helgoland population, may not be explained by 'ephemeral mode of life' or 'abiotic disturbance'. 
In this paper we address 3 main questions:

- Are shells from the unfouled population (Helgoland) inherently suitable for fouling?

- Does Littorina littorea possess any kind of antifouling defence?

- Why do the 2 Littorina littorea populations exhibit such different aspects of epibiosis?

\section{MATERIAL AND METHODS}

Study populations. Two distinct groups were used for our study:

Helgoland population: This population is abundant in the intertidal zone around the island of Helgoland (North Sea, 54 $11^{\prime} \mathrm{N}, 7^{\circ} 53^{\prime} \mathrm{E}, 33 \%$ salinity). Littorina littorea abundances in the collection area are $100 \mathrm{~m}^{-2}$ (Janke 1989). Twice daily, during low tide, these gastropods are exposed for several hours and they usually, but not always, aggregate or seek shelter in moist places. For experiments in the brackish Baltic, these snails were slowly $\left(-0.5 \% \mathrm{~h}^{-1}\right)$ adapted to $17 \%$, a salinity they can tolerate without apparent harm for at least 1 yr (pers. obs.).

Kiel Bight snails: The Baltic Littorina littorea were collected from 1 to $4 \mathrm{~m}$ depth in a boulder field near Strande, Germany (54 $26^{\prime} \mathrm{N}, 10^{\circ} 10^{\prime} \mathrm{E}, 17 \pm 5 \%$ salinity). There are no tides in the Baltic and the snails are rarely found emersed. Natural population density, assessed by SCUBA diving (240 randomly positioned $315 \mathrm{~cm}^{2}$ frames), was $3 \mathrm{~m}^{-2}$ for adult snails.

Fouling experiments were performed at an underwater station (4 to $5 \mathrm{~m}$ depth) ca $4 \mathrm{~km} \mathrm{NE}$ of Strande in the Kiel Bight and surveyed by SCUBA diving.

Epibionts on living Littorina littorea. Sessile organisms on randomly chosen, live snails from Helgoland ( $n=74$; March 1990) and Kiel Bight ( $n=56$; December 1989. May and October 1990) were assessed under a stereomicroscope. Larger animals (barnacles, mussels, some polychaetes) were counted. The relative abundances of smaller and often more numerous colonizers (ciliates, filamentuous algae, polychaetes, etc.) were arbitrarily classified, species by species, as absent $(0)$. rare (1), abundant (2) or dominant (3). The coverage by unidentified algal crusts was visually estimated to the nearest $10 \%$ for each individual. The same was done for the epibiotic community as a whole, excepting algal crusts but including all other epibionts. Only the intact shell surface was taken into account. Thus, organisms colonizing erosion crevices or abandoned Polydora ciliata holes did not contribute to the estimate of overall coverage.

Colonization of dead Littorina littorea shells. In order to examine the inherent fouling properties of the shell, 16 originally epibiont-free snails from Helgoland were killed by deep-freezing. Subsequently, the body of the snail was removed and the shells divided into 2 lots of 8 and exposed $1 \mathrm{~m}$ above ground at the experimental site for 3 mo (winter 1989/spring 1990) and 5 mo (summer/autumn 1990) respectively.

Antifouling defences. Mechanical defence: To check for sloughing, abrasion or any other physical instability of the shell surface, we applied dots of nail polish on 20 Littorina littorea. Ten snails were kept in an aquarium at a density of 100 snails $\mathrm{m}^{-2}$. Presence and size of the dots were checked every 2 wk for 6 mo. The remaining 10 individuals were part of the Expt 2 snails (see below). The condition of the dots was noted at the end of the 2 mo exposure.

Physical defence: Surface tension of the shell, which might play a role in the initial steps of fouling (e.g. Goupil et al. 1980), was measured by a slightly modified version of the adhering bubble method of Neumann \& Good (1979, for details see Wahl \& Banaigs 1991).

Chemical defence: Whole snails (body and shell) were extracted successively with hexane, dichloromethane, butanol, ethanol and methanol. Subsequently, the filtered solutions were evaporated and the extracts weighed and redissolved in their respective solvent at $10 \mathrm{mg} \mathrm{ml} \mathrm{m}^{-1}$.

- Paper disk diffusion test $(1000,300$ and $100 \mu \mathrm{g}$ extract per disk): The extracts were tested for bacterial growth inhibition against 4 bacterial strains $(2$ Gram+ rods, 1 Gram+ coccus and 1 Gram- rod) isolated from living and non-living marine surfaces. Anti-algal activity was assessed using the chlorophyte Nannochloris sp. as a target organism. The cyanobacterium Anabaena sp. was used to reveal any anti-cyanobacterial activity.

- Liquid media LD100 tests (100 and 500 ppm extract): Anti-ciliate tests were performed using Tetrahymena thermophila as test organism. For anti-diatom tests we used Skeletonema costatum and Navicula sp.

Activity was measured as inhibition zone diameter (IZD) in the paper disk diffusion tests and as LD 100 extract concentration for the liquid media tests. Every test was run with 2 replicates. Solvent-only controls were conducted simultaneously.

Influence of Littorina littorea population density on shell fouling. Population density related effects on the development of the epibiotic community on live shells were evaluated in 3 different experiments (Table 1). Snails were enclosed at varying abundances in perforated, partly transparent plexiglass boxes and exposed at the experiment site $1 \mathrm{~m}$ above ground.

Expt 1. Infiluence of snail density on microfouling: After 1.5 mo exposure of 10 Helgoland snails at 3 different densities (alone, 213 and $426 \mathrm{~m}^{-2}$ ), diatoms 
Table 1 Littorina littorea. Experimental conditions (snail density and exposure data) for Expts 1 to 3

\begin{tabular}{|c|c|c|c|c|c|c|}
\hline $\begin{array}{l}\text { Experiment } \\
\text { Date }\end{array}$ & $\begin{array}{c}\text { Inner box } \\
\text { surface }\left(\mathrm{cm}^{2}\right)\end{array}$ & $\begin{array}{l}\text { No. snails } \\
\text { box }\end{array}$ & $\begin{array}{l}\text { No. snails } \\
\mathrm{m}^{-2}\end{array}$ & No. boxes & No. snails & $\begin{array}{l}\text { No. snails } \\
\text { examined }\end{array}$ \\
\hline Expt 1 & 94 & 1 & - & 2 & 2 & 2 \\
\hline \multirow[t]{2}{*}{5 Apr-17 May 1990} & & 2 & 213 & 2 & 4 & 2 \\
\hline & & 4 & 426 & 1 & 4 & 2 \\
\hline Expt 2 & 1580 & 1 & - & 6 & 6 & 6 \\
\hline 1st lot: & & 2 & 12 & 4 & 8 & 8 \\
\hline 5 Jun-16 Aug 1990 & & 5 & 32 & 4 & 20 & 14 \\
\hline 2nd lot: & & 10 & 63 & 3 & 30 & 14 \\
\hline 22 Aug-22 Oct 1990 & & 20 & 127 & 3 & 60 & 14 \\
\hline Expt 3 & 154 & 1 & - & 24 & 24 & 24 \\
\hline Oct $1990-$ Oct 1991 & & 4 & 250 & 6 & 24 & 24 \\
\hline
\end{tabular}

and choanoflagellates were counted by scanning electron microscopy (SEM) (10 randomly chosen $100 \times$ $100 \mu \mathrm{m}$ squares per snail)

Expt 2. Macrocolonization as a function of snail abundance: Helgoland snails, previously epibiontfree, were enclosed for 2 mo at 5 different densities (alone, 12, 32, 63 and 127 snails $\mathrm{m}^{-2}$ ). Algal and ciliate abundances were estimated on a subsample of the test snails only.

Expt 3. Effects of snail density on epibiotic development and recruitment: Forty-eight moderately fouled Baltic Littorina littorea (ca $20 \%$ initial overall coverage) were enclosed alone or at 4 box ${ }^{-1}\left(250 \mathrm{~m}^{-2}\right)$ and exposed in situ for $12 \mathrm{mo}$. At 2 to $4 \mathrm{wk}$ intervals (February date missed because of adverse weather) shell epibiosis was assessed as described above on board the diving boat.

Statistics. Significance of differences in shell epibiosis were tested using the non-parametric MannWhitney $U$-test as recommended by Zar (1984). Significance level was $99 \%$ unless indicated otherwise in 'Results' To avoid pseudoreplication, the 4 snails in a given group box (experimental unit) of Expt 3 were considered interdependent. Consequently, we employed the averages of the 4 snails per group box as the observations making up the sample 'group' snails. Thus, in this sample for each epibiotic taxon considered $n=6$ ( 6 group boxes) whereas the sample 'solitary' snail contained 24 independant observations in each category (Hurlbert 1984). The design of the experiment does not allow one to statistically analyze the divergent development of the epibiotic community in the course of this 12 mo experiment, because the snails examined every 2 to 4 wk were always the same 48 individuals

Rhythms of Littorina activity and 'mutual grazing'. In order to establish activity rhythms of Littorina littorea that might help explain the influence of 'population density' on shell fouling, 20 snails held under aquarium conditions for $4 \mathrm{wk}$ were put in a plexiglass tank with an inner surface of $1900 \mathrm{~cm}^{2}$. Thus, snail density matched natural Helgoland conditions. The snails were videofilmed for $70 \mathrm{~h}$, using white artificial light during daytime (5:00 to 21:00 h) and infrared illumination during the night. Subsequently, the number of actively crawling snails (general activity) and of individuals carrying at least 1 other snail on their back ('grazing' activity) was recorded every 30 and $15 \mathrm{~min}$, respectively.

\section{RESULTS}

\section{Epibiotic situation of Littorina littorea}

The populations from Helgoland and from Kiel Bight exhibited conspicuously and significantly different degrees of epibiosis $(p<0.001)$. The North Sea snails were typically free of (macro-) epibionts and their shells showed no erosion. Only 2 individuals of the barnacle Elminius modestus were found on the 74 snails examined. Mean coverage in this population was less than $1 \%$. The Baltic snails were more heavily colonized: $13 \pm 16 \%$ overall coverage. Frequent epibionts were barnacles (mostly Balanus crenatus), juvenile mussels, the polychaetes Polydora ciliata and Fabricia sabella, the tube dwelling amphipod Corophium volutator and non-identified encrusting brown algae. More rarely found were filamentous and juvenile red and brown algae, the bryozoans Alcyonidium polyoum and Electra pilosa, and the hydrozoans Clava multicornis and Coryne decipiens. The erosion of the shells was often heavy and probably due to the boring activity of $P$. ciliata. There was a tendency for balanids, mussels and $F$. sabella to be more abundant on autumn and winter shells, while non-encrusting algae were only found in summer. 


\section{Colonization of dead Littorina shells}

The empty shells were colonized rapidly by juvenile mussels, hydrozoans, red and brown algae in spring [final coverage after 3 mo exposure: $67 \pm 27 \%(n=8)$ ] and by barnacles, juvenile mussels, filamentuous algae, ciliates (Vorticella sp., Folliculina sp., Zoothamnium sp.) hydrozoans and rhodophyta in late summer [final coverage after 5 mo exposure: $34 \pm 16 \%$ ( $\mathrm{n}=8)$ ). The more extensive occupation of shell space in spring was due mainly to a spat fall of Mytilus edulis and the abundant recruitment of phaeophyta.

These observations show that the shells of (dead) Helgoland Littorina littorea represent a suitable substratum for colonization. Within 3 to 5 mo the coverage values of dead shells exceeded those of living Baltic snails 2- to 5-fold and those of living Helgoland Littorina littorea by a factor exceeding 40 .

\section{Antifouling defences}

Mechanical. The surface of the shell does not seem to slough, peel off or abrade within any time interval relevant for fouling: dots of nail polish applied onto the shell of live snails remained stable over a 2 (in situ) to 6 mo (aquarium) period.

Physical. It is difficult to measure surface tension by the adhering bubble method with any precision on the rather rough Littorina littorea shell surface. Nevertheless, our results revealed that the shell's surface tension is undoubtedly higher than 50 dynes $\mathrm{cm}^{-1}$ and, consequently, lies well outside the (theoretically) fouling impeding 'biocompatible range' of 20 to 30 dynes $\mathrm{cm}^{-1}$.

Chemical. The 5 Littorina littorea extracts showed no anti-bacterial activity at $1000 \mu \mathrm{g} \mathrm{disk}^{-1}$ and only a slight anti-cyanobacterial activity (methanol extract: IZD $=15$ $\mathrm{mm}_{i}$ butanol extract: $\mathrm{IZD}=11 \mathrm{~mm}$ ) at $300 \mu \mathrm{g} \mathrm{disc}^{-1}$. There was no anti-diatom or anti-flagellate activity at $100 \mathrm{ppm}$ and no anti-ciliate activity at $500 \mathrm{ppm}$. The methanol and butanol extracts exhibited a weak inhibitory effect on chlorophyte growth at $300 \mu \mathrm{g} \mathrm{disc}^{-1}$ (IZD: $19 \mathrm{~mm}$ and $13 \mathrm{~mm}$ respectively). Consequently, mechanical, physical and chemical antifouling defences seem to be negligeable or nonexistant in Littorina littorea.

\section{Influence of Littorina littorea population density on fouling}

Microfouling (Expt 1). Five genera of diatoms were encountered on the shells. In decreasing order of abundance they were: Cocconeis > Synedra > Navicula and Amphora > Licmophora. The final diatom abundance on the shells seemed inversely correlated to snail density (Fig. 1). Between 213 and 426 snails

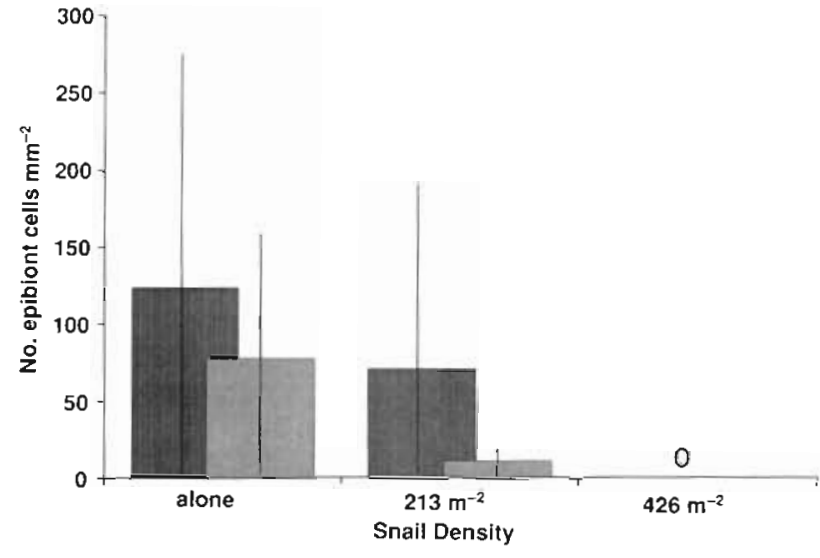

Fig. 1. Littorina Iittorea. Microfouling (no. cells $\mathrm{mm}^{-2} \pm \mathrm{SD}$ ) on shells of snails kept at different densities after 6 wk exposure (Expt 1). Dark bars: choanoflagellates; light bars: diatoms

$\mathrm{m}^{-2}$, a critical population density is reached which inhibits any epibiotic diatom growth.

The only choanoflagellate found on Littorina littorea was a form resembling Acanthoeca sp. The recruitment and/or development of the choanoflagellate, too, seemed to be inhibited at high snail densities $\left(426 \mathrm{~m}^{-2}\right)$ (Fig. 1).

Macrofouling (Expt 2). Increased Littorina littorea densities reduced the recruitment of all assessed macroepibionts on the shells. Filamentuous algae showed the most conspicuous effects. Final overall coverage ranged from over $70 \pm 23 \%$ on the solitary snails to less than $10 \pm 8 \%$ on the snails caged at $127 \mathrm{~m}^{-2}$ (Fig. 2). At densities of $32 \mathrm{~m}^{-2}$ and higher the reduction in overall coverage of the shells, as compared to solitary snails, was significant.

Dynamics of epibiosis (Expt 3). Initial overall coverage of the snails was ca $20 \%$. Common epibionts

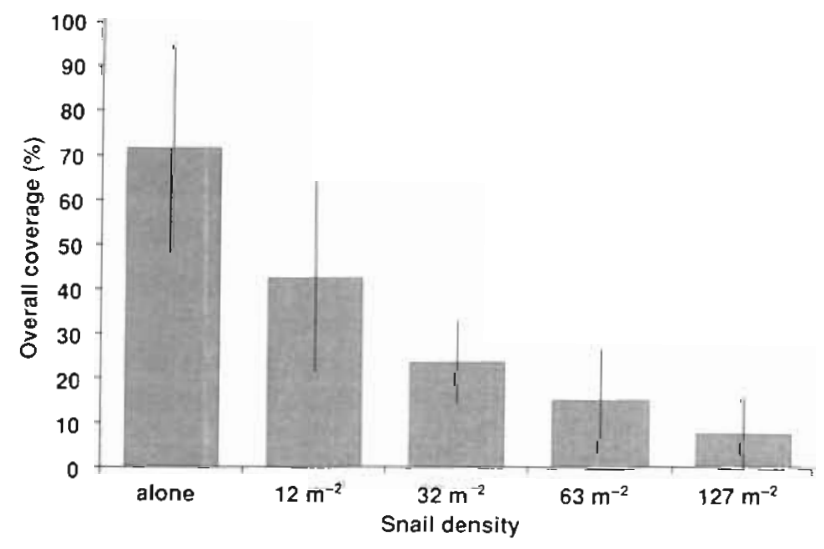

Fig. 2. Littorina littorea. Overall coverage $(\% \pm \mathrm{SD})$ of snails caged at different population densities after 2 mo exposure (Expt 2) 
in this season (October 1990) were nonidentified encrusting phaeophyta, juvenile Mytilus edulis, Polydora ciliata, Fabricia sabella, Corophium volutator and Balanus crenatus. During the 12 mo of enclosure the epibiotic community developed very differently on solitary and on group snails (Table 2, Figs. 3 to 5). Note that between April and July 1991 filamentous algae were growing so densely on solitary snails that smailer epibionts such as ciliates and polychaetes were difficult, sometimes impossible, to count.

Epibionts largely indifferent to snail density: Encrusting brown algae, the rarely observed hydrozoans, Fabricia sabella, Corophium volutator, Mytilus edulis (Fig. 4a) and Polydora ciliata (Fig. 4b), once settled, are little affected by grazing or bulldozing. The crusts and the hydrozoans might be defended, the mussels at the time of secondary spatfall usually are too big to be grazed, and the remainder of the unaffected species live cryptically.

Epibionts affected by snail density: Balanus crenatus. Balanids having passed a critical size (ca 0.5 to $1 \mathrm{~mm}$ ) were unaffected by high Littorina littorea densities. On the other hand, grazing or bulldozing apparently effectively inhibited further barnacle recruitment on group shells. This is illustrated by the relatively constant number over 12 mo of (postthreshhold) Balanus crenatus on group snails (Fig. $4 \mathrm{c})$. Contrarily, the density of barnacles on the solitary snails steeply increases after a late autumn spat fall (1990) and stabilizes on a level ca 4 times higher than $B$. crenatus coverage on group snails. This difference was conspicuous but not significant at the 0.01 level.

Ciliata. Vorticella sp. and, to a lesser extent, Zoothamnium sp. massively recruited in February and March 1991. While they quickly covered solitary shells almost entirely and persisted at a high density until being masked by filamentous algae, they only recruited in low abundance on group snails and disappeared completely within $6 \mathrm{wk}$ (Fig. $4 \mathrm{~d}$ ). The differences were significant from March through May when the ciliates became hidden under the ectocarpales on solitary snails. By September the ciliates had disappeared from all snails.

Filamentous phaeophyta (Fig. 4e). The ectocarpales population literally exploded on solitary shells from April 1991 onwards, whereas they stayed completely absent from the shells of group snails. By June most solitary snails exhibited ectocarpales mats up to $5 \mathrm{~mm}$ thick which masked most other epibionts. The differences between the 2 snail groups were significant over 7 mo until in September the algal mats started to disintegrate and peel off. Apparently, under the mats an anoxic milieu had developed, because much of the newly appearing shell surface was quite black and epibionts previously found on a given individual had been killed (e.g. barnacles) or simply disappeared (e.g. Polydora ciliata).

Other algae. On solitary snails germlings of thalloid red, green and brown macroalgae first recruited during May 1991. At this juvenile stage it proved impossible to identify the algae and they were simply classified as rhodo-(Fig. 4f), chloro-(Fig. 4g) and phaeophyta (Fig. 4h). Contrarily, on group snails no algae settled in any permanent manner. Only in October when snail densities in the group boxes dropped drastically, some red and brown algae successfully recruited on these snails. The differences in algal fouling on the 2 snail groups was significant $(p<0.05)$ in June and partly significant (rhodophyta) in July. Green algae and part of the brown algae naturally disappeared from the shells at the end of their growing season.

The quantitative aspect of this divergent evolution is best illustrated by the estimated overall coverage (in \%) on the snails of the 2 groups (Fig. 5). Initially, mean epibiotic coverage was ca $20 \%$ for both groups (October 1990). During winter, coverage gradually diminished on group snails, while it slightly rose on solitary snails due to the recruitment of barnacles. In the beginning of spring (4 April 1991) solitary snails exhibited $27 \%$ of mean coverage, whereas the surface of group snail shells was only colonized to $8 \%$. The ciliates, which in February/March had recruited on solitary snails in extremely high numbers contributed little to the coverage estimates which were done at very low magnification. The very steep increase in coverage of solitary snails during April/May (absent from group snails) was due to the explosive development of ectocarpales. A further increase in June 1991 reflects the recruitment of foliose red, green and brown algae on solitary snails. All of these colonizing events (barnacles, ciliates, filamentous algae, foliose algae) were completely or nearly completely, suppressed on the group snails. While the differences in coverage between the 2 snail groups were significant during all of spring and summer 1991, they were most spectacular at the peak of algal recruitment in June, when on average solitary snails were covered to $95 \%$ and group snails only to $7.5 \%$. The decrease in coverage of solitary snails during summer was due to the peeling off of the ectocarpales mats. The autumn increase of fouling (macroalgae, Fabricia sabella) in the group snails was probably a consequence of an increased mortality of snails in the group boxes (September/October, Fig. 6), which led to a decrease in snail density, thus apparently removing the main obstacle to fouling by certain epibionts. The suddenly increased mortality in autumn was obviously related to an extremely heavy Mytilus edilus spatfall. As this was a secondary spatfall, the young mussels were 


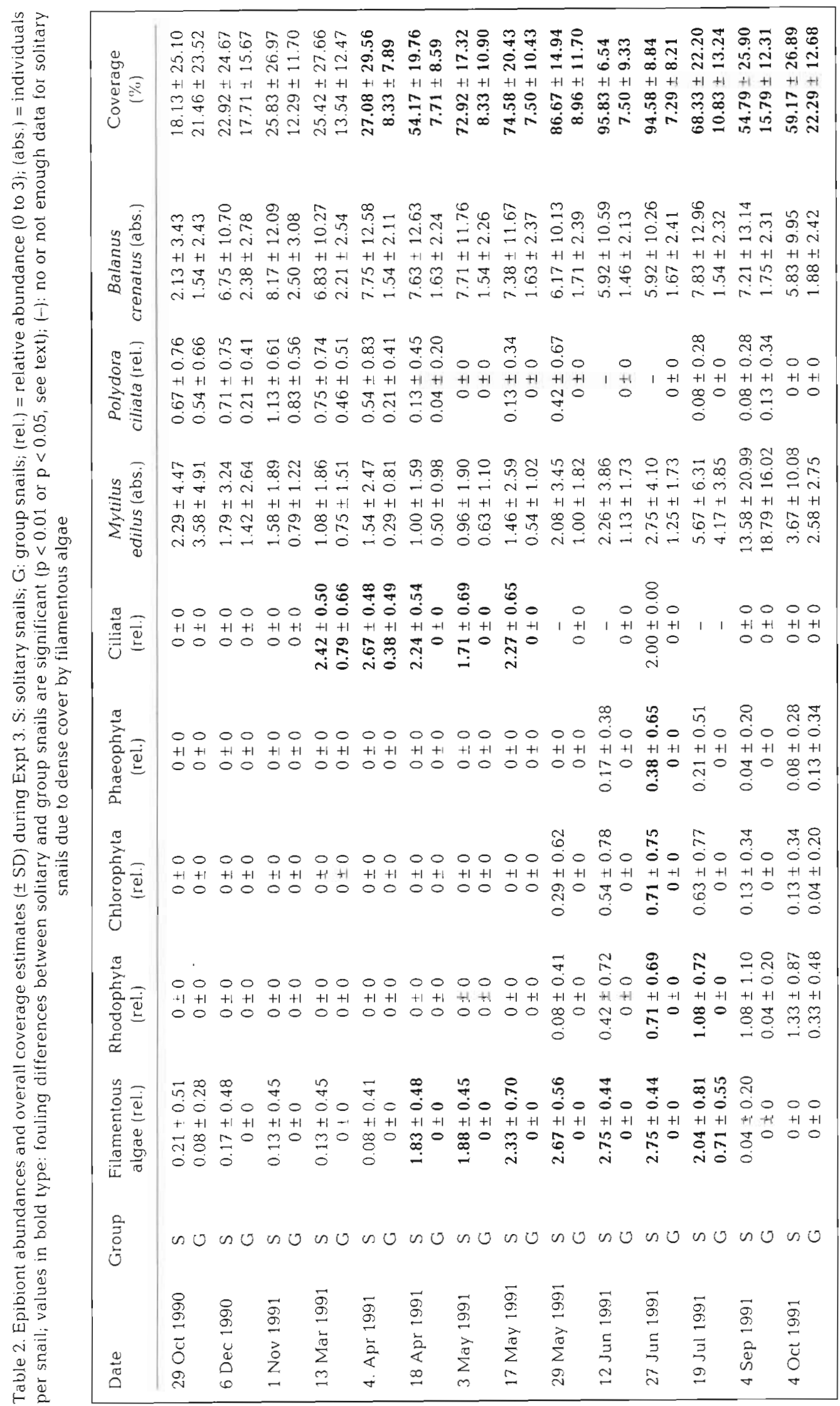


Fig. 3. Littorina littorea. Two unfouled (left) 'group' snails and two 'solitary' snails fouled by algae (upper right) and balanids (lower right) in June 1991 after 7 mo enclosure (Expt 3)

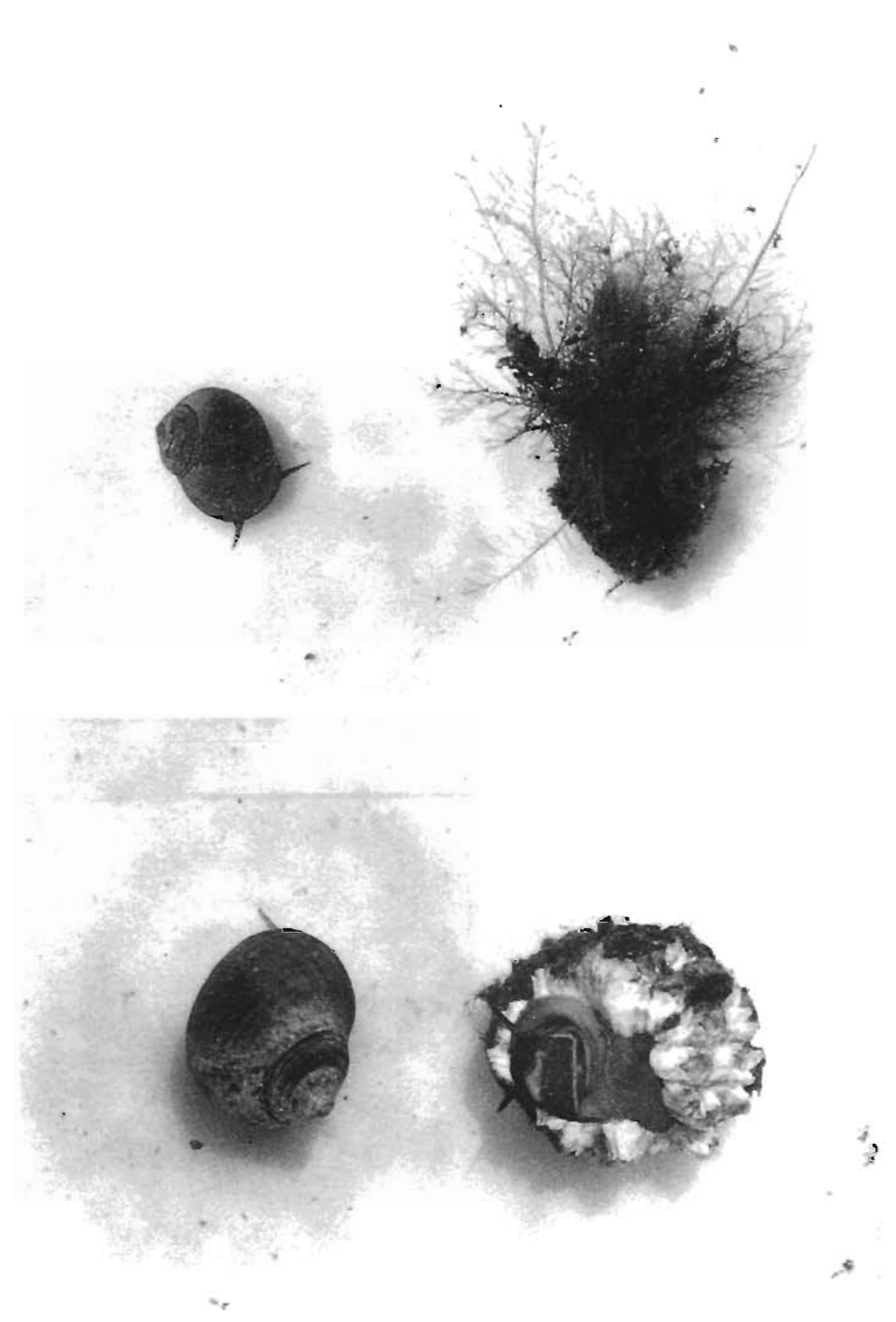

too big to be grazed, they grew quickly and soon entrapped many snails in their byssus. Group snails were more sensitive to this threat. They had less room at their disposal to avoid the byssus and, possibly, were more stressed by their relatively closer confinement. When the average snail density per group box dropped below ca $100 \mathrm{~m}^{-2}$ in September, the difference in coverage between the 2 snail groups was shrinking towards the insignificance level.

\section{Crawling and grazing rhythms of Littorina littorea}

The test snails were mostly active during daylight (Fig. 7). A conspicuous activity minimum falls between midnight and 'dawn' (05:00 h). On an hourly average, crawling activity oscillated between 1 and $50 \%$. During this exploratory or grazing-related crawling numerous individuals were observed passing over the shells of other snails. For the given snail density of $105 \mathrm{~m}^{-2}$ the 

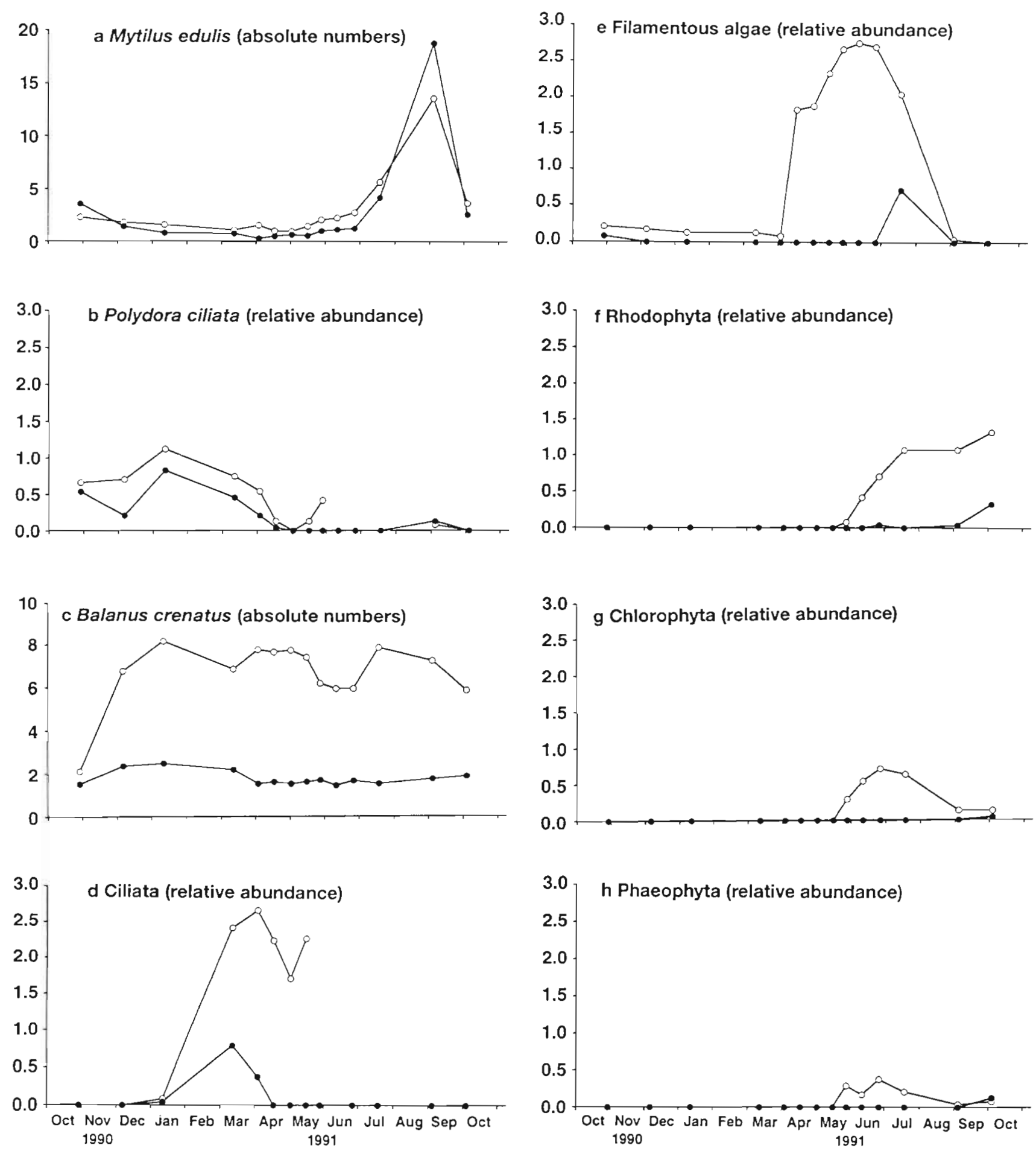

Fig. 4. Littorina littorea. Abundances of different epibiont species found on snail shells during Expt 3. ( $\bullet$ ) 'group' snails; (O) 'solitary' snails. Missing data points: readings made impossible by thick algal mat on snails. For SD see Table 2

'mutual grazing' curve runs roughly parallel to the crawling activity curve with a minimum between $02: 00$ and 04:00 h and a maximum (1.2 individuals 'grazed' at any instant) between 10:00 and 14:00 h. At any given moment a mean of $0.59 \pm 0.74$ individuals out of 20 are 'grazed upon', which signifies that at this population

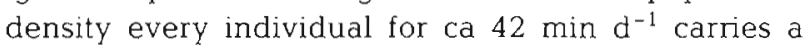
crawling (and grazing?) snail on its shell. 


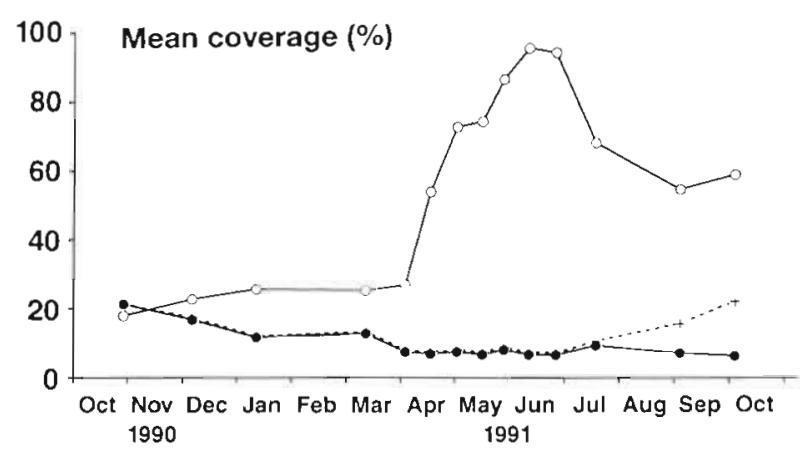

Fig. 5. Littorina littorea. Mean overall coverage on shells during Expt 3. (---+---) original data for 'group' snails; $(--)$ same data corrected for autumn snail mortality $1 \%$. $=\% \times 4$ (no. of snails per box) $/ n$ (actual no. of snails per box)]; $(\multimap-)$ solitary snails

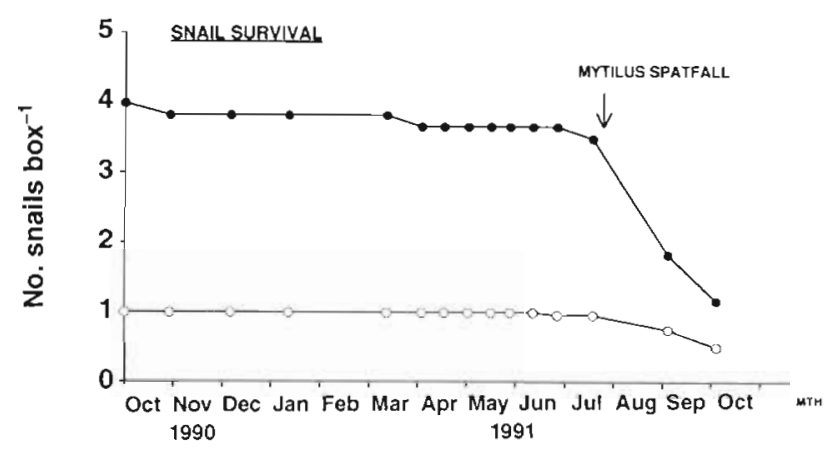

Fig. 6. Littorina littorea. Snail survival. (•) mean no. snails in 'group' boxes; (0) mean no. snails in solitary boxes

\section{DISCUSSION}

Theoretically, epibiosis may entail numerous disadvantages and benefits for animals such as benthic snails. Among the most important potential effects should be (1) protection through camouflage against predators (positive), (2) risk of shell destruction by boring organisms (negative), (3) protection against desiccation (positive) and (4) enhanced risk of dislocation by currents and waves (negative). The last 2 aspects are relevant mainly to the
Helgoland intertidal population, because the Baltic snails are not exposed to tides or high water velocities. While Helgoland Littorina littorea are generally devoid of epibionts, the Baltic population tolerates at least a moderate degree of fouling. Several biological or abiotic parameters might be responsible for this epibiotic difference:

(1) Defenses. Neither Helgoland nor Baltic snails exhibit any significant mechanical, physical or chemical antifouling adaptations. When exposed under identical conditions specimens of both populations are colonized at the same rate. Apparently snails of both populations are a priori equally suitable to fouling.

(2) Physical stress. While exposure at low tide is certainly stressfull to some epibionts, the abiotic strain excerted by the intertidal habitat can not be the only factor limiting epibiosis on Helgoland snails: there are intertidal North Sea populations that do get fouled (near Büsum, Germany) and Helgoland snails do stay epibiont-free in the Baltic when caged at high densities.

(3) Population density of the snails, on the other hand, strongly affects the dynamics of development and/or persistance of a shell epibiotic community. At low snail densities $\left(<60 \mathrm{~m}^{-2}\right)$, originally epibiont-free snails (Expts 1 and 2) are colonized intensively by diatoms, choanoflagellates, macroalgae, sedentary polychaetes, mussels, etc. within a few (summer-) weeks. Contrarily, at high snail abundances ( 60 to $426 \mathrm{~m}^{-2}$, Expts 1 to 3 ) the establishment of an epibiotic community is conspicuously hindered. The snail densities used in these studies fall within the described natural range of Littorina littorea abundance: $100 \mathrm{~m}^{-2}$ (Janke 1989), $134 \mathrm{~m}^{-2}$ (Watson \& Norton 1985), $280 \mathrm{~m}^{-2}$ (Lubchenco 1983), $500 \mathrm{~m}^{-2}$ (Hunter \& RussellHunter 1983), $600 \mathrm{~m}^{-2}$ (Petraitis 1987).

These experimental findings correspond well to the situation found in the field: Baltic Littorina littorea were ca 100 times more densely fouled than North Sea snails (13 vs $0.14 \%$ ) and ca 33 times less abundant than Helgoland Littorina littorea (3 vs $100 \mathrm{~m}^{-2}$ ).
Fig. 7 Littorina littorea. Crawling and grazing activity of snails at 106 ind. $\mathrm{m}^{-2}$ (hourly means). $(---)$ no. individuals crawling; ( $\longrightarrow$ no. individuals being grazed upon. Three-day data (66 h) pooled into $24 \mathrm{~h}$

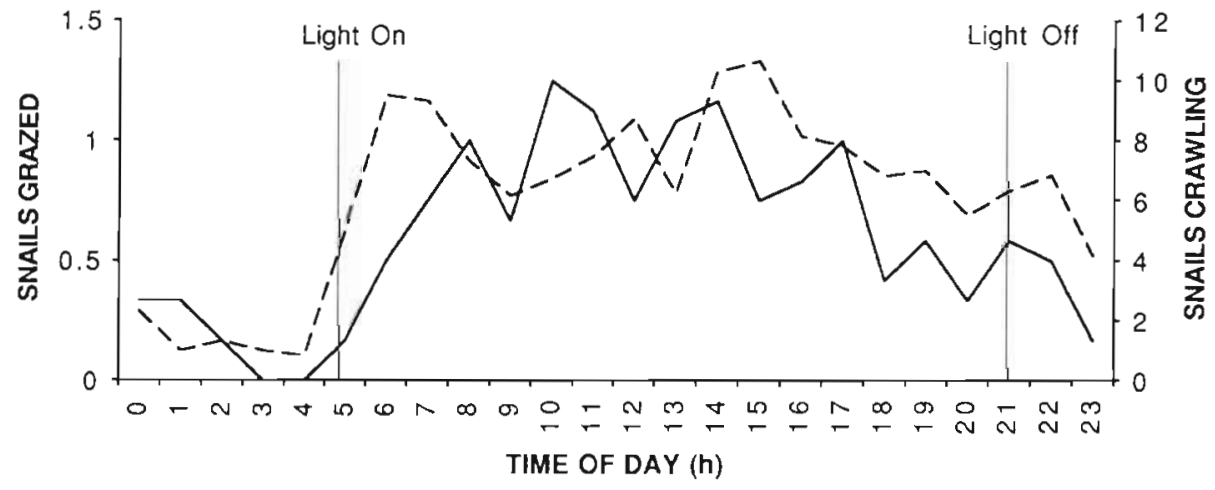


In our aquarium experiments at Helgoland population densities, each individual carries another snail on its shell for over $40 \mathrm{~min}^{-1}$, on average. This seems amply sufficient to account for the observed control of fouling on snails at $60 \mathrm{~m}^{-2}$ or denser. Three potentially fouling-reducing factors may act during the passage of a snail over another's shell: (1) mechanical effects of the (non-toxic) mucus secreted by the passing snail's foot leading to reduced exchanges, clogging of cilia, etc. of some epibionts, (2) 'accidental' mechanical removal or destruction of epibionts ('bulldozing'), and (3) grazing.

Most fouling species particularly inhibited on group snails fall within the described dietary range of Littorina littorea: diatoms (Hunter \& Russell-Hunter 1983, Petraitis 1983, Watson \& Norton 1985), foliose and filamentuous algae (Lubchenco 1983, Watson \& Norton 1985) and germlings of perennial algae (Watson \& Norton 1985, Petraitis 1987). The development of the epibiotic communities on L. littorea shells as a function of 'snail density' is very similar to the results of enclosure/exclusion experiments with littorine grazers on rocky substrates as described by Bertness et al. (1983), Hunter \& Russell-Hunter (1983), Jernakoff (1983), Lubchenco (1983), Petraitis (1983, 1987), Watson \& Norton (1985): at high snail densities overall coverage decreases essentially by control through $L$. littorea grazing of diatoms, ephemeral algae and germlings and by inhibition of recruitment through the combined effects of browsing and bulldozing. In this study, within the first 7 mo of enclosure the number of macroepibiont species on group snails had decreased to less than $50 \%$ as compared to solitary snails. Interestingly, this is very close to the findings of Hunter \& Russell-Hunter (1983) for microfouling (mostly diatoms) on artificial substrata under littorine grazing pressure (ca $60 \%$ species richness reduction at ca 100 snails $\left.\mathrm{m}^{-2}\right)$. The third density-related factor, mucus secretion, has not been analyzed yet.

Summarizing, the effects of snail density (grazing pressure, bulldozing and/or mucus secretion) on the dynamics of hard bottom fouling communities and on shell epibiosis are akin in that they strongly reduce (shell) fouling in the density range of 60 snails $\mathrm{m}^{-2}$ or higher.

Even when antifouling defence mechanism is understood as any biological characteristic of a given species that - be it as a side-effect - reduces fouling like an ephemeral or burrowing mode of life), mutual grazing is not unproblematic to view as an antifouling defence: usually, defence adaptations are used to defend oneself, whereas in this case each individual snail for 'defence' depends completely on its conspecifics.

An alternative interpretation of the described Littorina littorea 'defence' could be found by employ- ing the concept of disturbance (Dayton 1971, Osman 1977, Sousa 1979), which demonstrates how free space may be created and maintained by high frequency disruptions of the colonizing process. We suggest that the repeated recruitment inhibition on and by group snails in this study be considered as biological disturbance. Littorine mutual grazing represents a way of keeping epibiosis at a minimum that is unlikely to be associated with the kind of costs described or postulated for many forms of defence (Fox 1981, Coley 1986, Fagerström 1989).

Acknowledgements. We are very grateful to Mark Hay (University of North Carolina) and Paul Dayton (SIO, University of San Diego) for their thoughtful comments on the manuscript. S. H. Hulbert (San Diego State University) gave precious advice on statistical analysis. A very thorough and constructive review of the manuscript by J.S. Pearse (U.C. Santa Cruz) significantly improved this paper.

\section{LITERATURE CITED}

Bertness, M. D., Yund, P. O., Brown, A. F. (1983). Snail grazing and the abundance of algal crusts on a sheltered New England rocky beach. J. exp. mar. Biol. Ecol. 71: 147-164

Coley, P. D. (1986). Costs and benefits of defense by tannins in a neotropical tree. Oecologia 70:238-241

Dayton, P. K. (1971). Competition, disturbance and community organization: the provision and subsequent utilization of space in a rocky intertidal community. Ecol. Monogr, 41: $351-389$

Fagerström, T. (1989). Antiherbivory chemical defense in plants: a note on the concept of cost. Am. Nat. 133: 281-287

Fox, R. F. (1981). Defense and dynamics in plant-herbivore systems. Am. Zool. 21: 853-864

Goupil, D. W., DePalma, V. A., Baier, R. E. (1980). Physical/ chemical characteristics of the macromolecular conditioning film in biological fouling. In: Haderlie, E. C., Tripper, R. C. (eds.) Proc. 5th int. Congr. Mar. Corrosion and Fouling, Madrid, p. 401-410

Hunter, R. D., Russel-Hunter, W. D. (1983). Bioenergetic and community changes in intertidal aufwuchs grazed by Littorina littorea. Ecology 64: 761-769

Hurlbert, S. H. (1984). Pseudoreplication and the design of ecological field experiments. Ecol. Monogr. 54: 187-211

Janke, K. (1989). Lebensgemeinschaften und ihre Besiedlungsstrukturen in der Gezeitenzone felsiger Meeresküsten. Ph.D. thesis, Univ. Kiel

Jernakoff, P. (1983). Factors affecting the recruitment of algae in a midshore region dominated by barnacles. J. exp. mar. Biol. Ecol. 67: 17-31

Lubchenco, J. (1983). Littorina and Fucus: effects of herbivores, substratum heterogeneity, and plant escapes during succession. Ecology 64: 1116-1.123

Neumann, A. W., Good, R. J. (1979). Techniques of measuring contact angles. Surf. Colloid Sci. 11: 31-91

Osman, R. W. (1977). The establishment and development of a marine epifaunal community. Ecol. Monogr. 47: 37-63

Petraitis, P. S. (1983). Grazing patterns of the perwinkle and their effect on sessile intertidal organisms. Ecology 64: $522-533$

Petraitis, P. S. (1987). Factors organizing rocky intertidal communities of New England: herbivory and predation in 
sheltered bays. J. exp. mar. Biol. Ecol. 109: 117-136

Sousa, R. (1979). Disturbance in marine intertidal boulder fields: the nonequilibrium maintainance of species diversity. Ecology 60: 1225-1239

Taylor, P. M., Andrews, E. B. (1988). Osmoregulation in the intertidal gastropod Littorina littorea. J. exp. mar Biol. Ecol. 122: 35-46

Wahl, M. (1989). Marine epibiosis. I. Fouling and antifouling: some basic aspects. Mar. Ecol. Prog. Ser. 58: 175- 189

This article was submitted to the editor
Wahl, M., Banaigs, B. (1991). Marine epibiosis. III. Possible antifouling defense adaptations in Polysyncraton lacazei (Didemnidae, Ascidiacea). J. exp. mar Biol. Ecol. 58: 175-189

Watson, D. C., Norton, T. A. (1985). Dietary preferences of the common perwinkle, Littorina littorea (L.). J exp. mar. Biol. Ecol. 88: 193-211

Zar, J. H. (1984). Biostatistical analysis, 2nd edn. PrenticeHall, Englewood Cliffs

Manuscript first received: March 31, 1992

Revised version accepted: September 15, 1992 